МУЛЛЕР О. Ю., РОТОВА Н. А.

СОЦИАЛЬНО-ПСИХОЛОГИЧЕСКАЯ АДАПТАЦИЯ СТУДЕНТОВ К ОБУЧЕНИЮ В ПЕДАГОГИЧЕСКОМ ВУЗЕ

РосСИйский психологИЧЕСКИй жУРнАл, 2020, Т. 17, № 3, 18-29. doi: 10.21702/rpj.2020.3.2

ПЕДАГОГИЧЕСКАЯ ПСИХОЛОГИЯ

УДК 159.923 .33 doi: $10.21702 /$ rpj.2020.3.2

Систематический обзор

\title{
Социально-психологическая адаптация студентов к обучению в педагогическом вузе
}

\author{
Ольга Ю. Муллер ${ }^{\text {* }}$, Наталья А. Ротова² \\ ${ }^{1}$ Сургутский государственный университет, г. Сургут, Российская Федерация \\ ${ }^{2}$ Сургутский государственный педагогический университет, г. Сургут, Российская Федерация \\ *E-mail: olga megion@mail.ru \\ ORCID ID: https://orcid.org/0000-0002-8938-5386, https://orcid.org/0000-0001-9792-7889
}

\begin{abstract}
Аннотация
Ввеление. В статье представлены результаты констатирующего этапа опытно-экспериментальной работы с целью выявления уровня аАаптированности студентов-первокурсников к обучению в педагогическом вузе, характеристик успешности социально-психологической алаптации студентов-первокурсников в педагогическом вузе. Определены компоненты социально-психологической аАаптации (Успешность в учебной Аеятельности, успешность в коммуникации), вылелены критерии и показатели Аля выявления алаптированности первокурсников: осознание новой роли студента, булущего педагога (проявляется через положительные результаты учебной Аеятельности) и взаимодействие с одногруппниками, преподавателями (проявляется через собственный стиль поведения, умение высказывать свою позицию и учитывать мнение собесеАников; способность принять и поААержать взгляАЫ и интересы оАногруппников).

Теоретическое обоснование. Представлены ретроспектива взгляАОв на феномен аАаптации, сравнительный анализ теоретических взгляАОв на понимание сущности понятия «аАаптация». Новизна исслеАования состоит в Уточнении понятия социально-психологической аАаптации студентов в педагогическом вузе с учетом эороективности процесса общения первокурсников с препоАавателями и оАногруппниками, наличия собственного стиля повеАения буАущего пелагога.
\end{abstract}

Результаты. Получены Аанные о высоком и среднем уровнях алаптации студентов к обучению в педагогическом вузе, что позволи^о сорормулировать рекоменАации Аля организации учебной Аеятельности с первокурсниками в педагогическом вузе, позволяющие студентам в более короткие сроки скоординировать свое повеление в соответствии с требованиями вуза. ОбсужАение результатов. Выявлены высокий уровень алаптации студентов в учебной группе и преоблаАающий среАний уровень аАаптированности к учебной Аеятельности. СлеАовательно, А^я преоАоления сложностей при освоении некоторых учебных Аисциплин необходимо организовать такую образовательную среАу, в которой у студентов будет возможность оценивать результаты собственной учебной Аеятельности, залавать вопросы Аля самоанализа, развивать способность к самоорганизации собственной Аеятельности.

Заключение. Результаты исследования предлагается использовать в работе преподавателей со стулентами-первокурсниками Аля выбора наиболее эфффективных фрорм работы, таких как интерактивные, способствующие успешной аАаптации к учебной Аеятельности. 
МУЛЛЕР О. Ю., РОТОВА Н. А.

СОЦИАЛЬНО-ПСИХОЛОГИЧЕСКАЯ АДАПТАЦИЯ СТУДЕНТОВ К ОБУЧЕНИЮ В ПЕДАГОГИЧЕСКОМ ВУЗЕ

РОССИЙСКИЙ пСИХОЛОГИЧЕСКИЙ ЖУРнАл, 2020, Т. 17, № 3, 18-29. doi: 10.21702/rpj.2020.3.2

ПЕДАГОГИЧЕСКАЯ ПСИХОЛОГИЯ

\section{КАючевые слова}

алаптация, алаптированность, профрессиональное самоопрелеление, самостоятельность, интерактивные метолы, самоорганизованность, студенты-первокурсники, адаптационный периол, мичностные качества, продрессиональные требования

\section{Основные положения}

> преполавателям, работающим в педагогическом вузе со студентами-первокурсниками, важно понимать сущность процесса алаптации, необхолимость созАания условий Аля успешного проявления возможностей и личных качеств стуАента в аАаптационный периоА с целью его самоорганизации;

$\checkmark$ А^я Успешного преоАоления сложностей при освоении учебных Аисциплин студентам-первокурсникам в педагогическом вузе необходимо развивать самостоятельность и самоорганизованность студентов через использование интерактивных фрорм обучения;

$>$ рассматривая период обучения в педагогическом вузе как этап продрессионального самоопределения, необхолимо использовать периол алаптации Аля выстраивания первокурсниками своей профрессиональной траектории развития с учетом соотнесения ^ичностных качеств и профрессиональных требований.

\section{Для цитирования}

Муллер, О. Ю. и Ротова, Н. А. (2020). Социально-психологическая адаптация студентов к обучению в педагогическом вузе. Российский психологический журнал, 17(3), 18-29. doi: 10.21702/rpj.2020.3.2

Дата получения рукописи: 23.05.2020 Дата окончания рецензирования: 08.06.2020 Дата принятия к публикации: 13.06 .2020

\section{Введение}

Жизненный этап человека - от рождения до смерти - идет рука об руку с непрерывным процессом адаптации (Росляков, 2003). Адаптация человека в обществе постоянных перемен проходит довольно сложно, человек не всегда успевает за быстро изменяющимися событиями (Налчаджян, 2008). В современном мире востребованы люди, способные осознать и понять свои ценности, использовать свой внутренний потенциал наиболее эффективно (KoeslagKreunen, Van der Klink, Van den Bossche, \& Gijselaers, 2018). Это во многом зависит как от самой личности, ее способности быстро реагировать на изменяющиеся условия, так и от внешних условий, например, среды педагогического вуза, специфика которой заключается в том, что для преподавателей важно понимать механизмы выстраивания процесса обучения, нацеленного на формирование у студентов профессиональных компетенций (Cabello, Sorrel, FernándezPinto, Extremera, \& Fernández-Berrocal, 2016).

Эффективность обучения современных студентов, по мнению Бредун с соавт., определяется степенью развитости метапредметных компетенций, уровнем сформированности готовности и способности к самоорганизации собственной деятельности (Бредун, Баланёв, Ваулина, Краснорядцева и Щеглова, 2020). Лазарев (2011) рассматривает концептуальную модель формирования профессиональных умений, построенную на основе принципов деятельностного подхода, как эффективный механизм результативного обучения в вузе. Однако на эффективность 
МУЛЛЕР О. Ю., РОТОВА Н. А.

СОЦИАЛЬНО-ПСИХОЛОГИЧЕСКАЯ АДАПТАЦИЯ СТУДЕНТОВ К ОБУЧЕНИЮ В ПЕДАГОГИЧЕСКОМ ВУЗЕ

РосСИйский психологИЧЕСКИй жУРнАл, 2020, Т. 17, № 3, 18-29. doi: 10.21702/rpj.2020.3.2

ПЕДАГОГИЧЕСКАЯ ПСИХОЛОГИЯ

образовательного процесса, выстраиваемого со студентами-первокурсниками в педагогическом вузе, в первую очередь оказывает влияние их успешная адаптация (Спаустинайтис, 2015). Поэтому очевидна необходимость научного осмысления вопроса социально-психологической адаптации студентов к обучению в педагогическом вузе. Необходимо уточнить, когда процесс адаптации студентов-первокурсников в педагогическом вузе можно считать успешным, рассмотрев подробнее критерии и показатели их социально-психологической адаптации к обучению. При рассмотрении данного вопроса нужно учитывать, что процесс обучения в вузе многими учеными понимается как этап в профессиональном самоопределении будущих педагогов (Пряжникова и Пряжников, 2013).

Разграничивая эффективность адаптации и адаптированности, Толстых (2011) относит критерии адаптации, собственно, к процессу, а критерии эффективности адаптированности к результату этого процесса. Исследователь доказывает взаимосвязь и взаимообусловленность уровня адаптированности первокурсников к обучению в вузе и эффективности системы адаптационных мероприятий, и приводит авторские критерии оценки результативности эффективности функционирования системы адаптационных мероприятий: удовлетворенность вузовским обучением, результативность обучения в вузе, активность в учебной и общественной жизни вуза, удовлетворенность собой как личностью.

Мы придерживаемся точки зрения Пряжниковой и Пряжникова (2013) и рассматриваем процесс обучения в вузе как этап профессионального самоопределения, который характеризуется следующими показателями: осознанием студентом своей новой социальной роли, осознанием смысла будущей профессии, соотнесением своих желаний с возможностями, осознанием потребности в профессиональном развитии. Следовательно, в адаптационный период при организации работы с первокурсниками важно создать такие условия, которые бы способствовали проявлению у студентов этих качеств в полной мере. Исследователями Верченко и Гриневой (2015) при изучении адаптации первокурсников были выделены следующие критерии: уровень вхождения в новую среду, поведение в условиях учебного заведения и знание о профессии, ценностные ориентации.

Учитывая понимание нами содержания понятия социально-психологической адаптации студентов-первокурсников в педагогическом вузе и рассматривая процесс обучения в вузе как этап профессионального самоопределения, выделим критерии и показатели социально-психологической адаптации студентов-первокурсников (табл. 1).

Таблица 1

Критерии и показатели социально-психологической алаптации студентов-первокурсников к обучению в педагогическом вузе

Компоненты ритерии

Успешность Осознание своей в учебной Аея- новой роли стулента, теАьности будущего пелагога
Положительные результаты учебной Аеятельности на основе понимания стулентом обучения в вузе как нового жизненного этапа и поиска нового смысла в педагогическом труле 
МУЛЛЕР О. Ю., РОТОВА Н. А.

СОЦИАЛЬНО-ПСИХОЛОГИЧЕСКАЯ АДАПТАЦИЯ СТУДЕНТОВ К ОБУЧЕНИЮ В ПЕДАГОГИЧЕСКОМ ВУЗЕ

РОССИЙСКИЙ пСИХОЛОГИЧЕСКИЙ ЖУРнАл, 2020, Т. 17, № 3, 18-29. doi: 10.21702/rpj.2020.3.2

ПЕДАГОГИЧЕСКАЯ ПСИХОЛОГИЯ

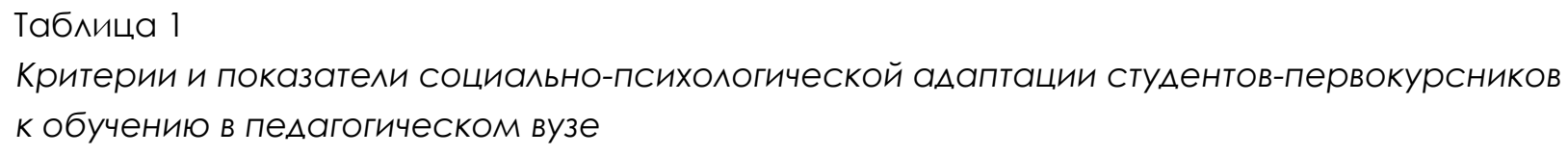

Компоненты алаптации

Критерии

Показатели

Собственный стиль поведения на основе уверенности

Успешность

Взаимодействие

в правильности профессионального выбора;

в коммуникации

С ОАНОгруппниками,

преполавателями

умение высказывать свою позицию, учитывать мнение

собесеАников; способность принять и подАержать

взгАяАЫ и интересы оАногруппников

\section{Теоретическое обоснование}

В настоящее время проблема адаптации личности, особенно молодежи на первом этапе профессиональной подготовки, является актуальной (Artunduaga, Munoz, \& Rojas, 2018). Адаптационным исследованиям посвящены работы таких зарубежных исследователей, как К. Роджерс, Р. Даймонд, А. Бандура, Г. Гартманн, А. Басс, Л. Берковитц, Г. Айзенк, К. Леви, К. Лоренц, 3. Фрейд и др. Различные аспекты изучения социально-психологической адаптации рассмотрены в трудах отечественных психологов А. Г. Маклакова, С. В. Чермянина, В. В. Грищенко, Н. Е. Шустовой, Т. В. Барлас, А. Г. Амбрумовой, А. Г. Асмолова. При рассмотрении социально-психологической адаптации мы опираемся на ряд концепций адаптации личности. В контексте гуманистического направления психологии проблемы адаптации анализируются с точки зрения идеального взаимодействия человека с окружающей средой (Beneyto-Seoane \& Collet-Sabé, 2018). В работах Дж. Олпорта, А. Маслоу, К. Роджерса, В. Франкла цель адаптации состоит в достижении позитивного духовного здоровья и согласовании ценностей личности и общества. В гуманистической психологии представлены диспозиции идеального взаимодействия личности и среды в динамике (Kim \& Klassen, 2018).

Обращаясь к разработанной Л. Филлипсом концепции интерактивной адаптации, Осницкий (2004) отмечает, что типы адаптации, отвечающие минимальным требованиям и социальным ожиданиям, могут быть вызваны факторами окружающей среды и внутрипсихическими факторами.

Гартман (2010), исследуя поведение личности в адаптационный период, отмечает, что между личностью и окружающей средой устанавливаются отношения адаптации, включающей в себя процессы, связанные с бесконфликтной сферой и конфликтными ситуациями.

Эффективность адаптации может быть представлена различными критериями. Среди многообразия представленных в психологической литературе критериев нам импонирует представление К. Мечковым и О. Ф. Гефеле таких критериев эффективной социально-психологической адаптации, как соизмеримость, своевременность, соответственность (Мечков, 1993) и моральная ориентация, принцип межличностных контактов, нервно-психическая устойчивость (Гефеле, 2003).

В идеях Маркаряна (1971) прослеживается мысль о том, что все общество является не только адаптивной (как биологическое общество), но и адаптивно-адаптирующей системой, поскольку 
МУЛЛЕР О. Ю., РОТОВА Н. А.

СОЦИАЛЬНО-ПСИХОЛОГИЧЕСКАЯ АДАПТАЦИЯ СТУДЕНТОВ К ОБУЧЕНИЮ В ПЕДАГОГИЧЕСКОМ ВУЗЕ

РоссиЙский псИХологИЧЕСКИй ЖУРнАл, 2020, Т. 17, № 3, 18-29. doi: 10.21702/rpj.2020.3.2

ПЕДАГОГИЧЕСКАЯ ПСИХОЛОГИЯ

деятельность человека, по сути, трансформирующая. Э. Маркарян, опираясь на идеи американского исследователя У. Бакли, считает, что общество, являясь адаптивно-адаптирующей системой, в процессе развития приобретает способность к существенным структурно-функциональным изменениям в целях самосохранения. Адаптации он отводит ключевую роль в понимании законов самоорганизации всех живых систем и определении критериев оценки концепций самоорганизации.

Адаптивность является результатом процесса адаптации. Некоторые авторы разводят данные понятия, а некоторые считают их синонимичными. Например, Серева и Андонова (2016), рассматривая актуальную проблему адаптации студентов к новым условиям, разделяют адаптацию на две составляющие - социально-психологическую и профессионально-учебную.

Изучая особенности процесса адаптации первокурсников в педагогическом вузе, Ермаченко, Зайцева и Середа (2017) указывают на необходимость изучения и учета многочисленных факторов, влияющих на степень адаптации,-это индивидуально-психологические особенности студентов, личностные, деловые и поведенческие качества, ценностные ориентации, академическая успеваемость, состояние здоровья, социальное окружение и т. д. Авторы отмечают, что при определении уровней адаптации первокурсников в педагогическом вузе важно учитывать приспособление студентов к новой системе обучения, к изменению учебного режима.

Адаптивные способности во многом приобретают зависимость от психологических характеристик личности, которые определяют способность адекватно регулировать функциональные состояния организма в различных условиях жизнедеятельности. Чем выше адаптивность, тем выше вероятность нормального функционирования организма и эффективность деятельности при увеличении интенсивности воздействия психогенных факторов окружающей среды (Свешникова, 2019). По мнению авторов Лызь и Шостак (2016), результативность процесса адаптации напрямую зависит от условий обучения в конкретном вузе.

Решение проблемы социально-психологической адаптации к обучению в высшем учебном заведении определяется психологическим своеобразием юношеского возраста (Maltese, Simpson, \& Anderson, 2018). В таком возрасте важно сформировать идеал будущей профессии и понять ее специфику (Cabello et al., 2016).

К сожалению, среди молодежи мы часто наблюдаем утрату доверия к окружающим, отсутствие межличностной поддержки, неуверенность в завтрашнем дне (Fan, 2016). В связи с этим процесс социально-психологической адаптации в вузе сопровождается психологическими трудностями: приспособление к вузовской системе обучения - самостоятельная организация учебы, усвоение большего объема информации, принятие новых ценностей и норм поведения, недостаток внимания (Власова, 2009).

Определение собственного видения мира содержит социальную направленность личности, организацию жизненных планов, формирование ценностных ориентаций и собственных интеллектуальных исследований (Semmler, Uchinokura, \& Pietzner, 2018). Поэтому мы рассматриваем профессиональное самоопределение студентов как процесс, который направлен на проявление своей индивидуальности, на развитие способности к самообразованию и самовоспитанию и умения сделать свой собственный выбор, на формирование личностных и профессиональных качеств.

При формировании личностных качеств студенты стремятся к самостоятельной жизни (With, 2017). Они считают себя взрослыми и полноправными членами общества, участвуют практически во всех видах социальной деятельности и выполняют множество социальных ролей. 
МУЛЛЕР О. Ю., РОТОВА Н. А.

СОЦИАЛЬНО-ПСИХОЛОГИЧЕСКАЯ АДАПТАЦИЯ СТУДЕНТОВ К ОБУЧЕНИЮ В ПЕДАГОГИЧЕСКОМ ВУЗЕ

РОССИЙСКИЙ ПСИХОЛОГИЧЕСКИЙ ЖУРНАЛ, 2020, Т. 17, № 3, 18-29. doi: 10.21702/rpj.2020.3.2

ПЕДАГОГИЧЕСКАЯ ПСИХОЛОГИЯ

Начинается процесс адаптации к педагогической сфере, овладение и принятие этических норм, профессиональной деятельности, профессионального общения и осознания важности будущей профессии и их участия в ней (Ranga \& Etzkowitz, 2015).

Мы будем рассматривать социально-психологическую адаптацию студентов к обучению в педагогическом вузе как процесс внутренних изменений будущих педагогов, результат которого прослеживается через эффективное общение с преподавателями и сокурсниками на основе выстроенного собственного стиля поведения, что связано с успешностью профессионального самоопределения, осознанием личностью смысла в выбранной трудовой деятельности и своих потребностей в дальнейшем профессиональном развитии.

На основе понимания сущности социально-психологической адаптации студентов к обучению в педагогическом вузе рассматривают такие ее виды, как адаптация к условиям учебной деятельности, к группе и к будущей профессии (Taylor, 2017).

\section{Результаты}

Для определения характерных особенностей социально-психологической адаптации студентов первого курса педагогического вуза был проведен констатирующий этап опытно-экспериментальной работы. Результаты диагностического исследования представлены методическим инструментарием «Адаптированность студентов в вузе» (Дубовицкая и Крылова, 2010).

Диагностическая методика предназначена для выявления уровня адаптированности студентов в вузе по двум шкалам, включающим изучение адаптированности к учебной группе и адаптированности к учебной деятельности.

Эмпирическая выборка формировалась из студентов первого курса Сургутского государственного педагогического университета, факультета психологии и педагогики. Объем выборки составил 104 испытуемых, что составляет 87 \% от общего количества всех первокурсников на факультете. Выводы о наличии достоверных характерных особенностей социально-психологической адаптации студентов первого курса педагогического вуза делались на основании процентного и количественного отношения по шкалам методик, результаты диагностики представлены на рисунках 1-4.

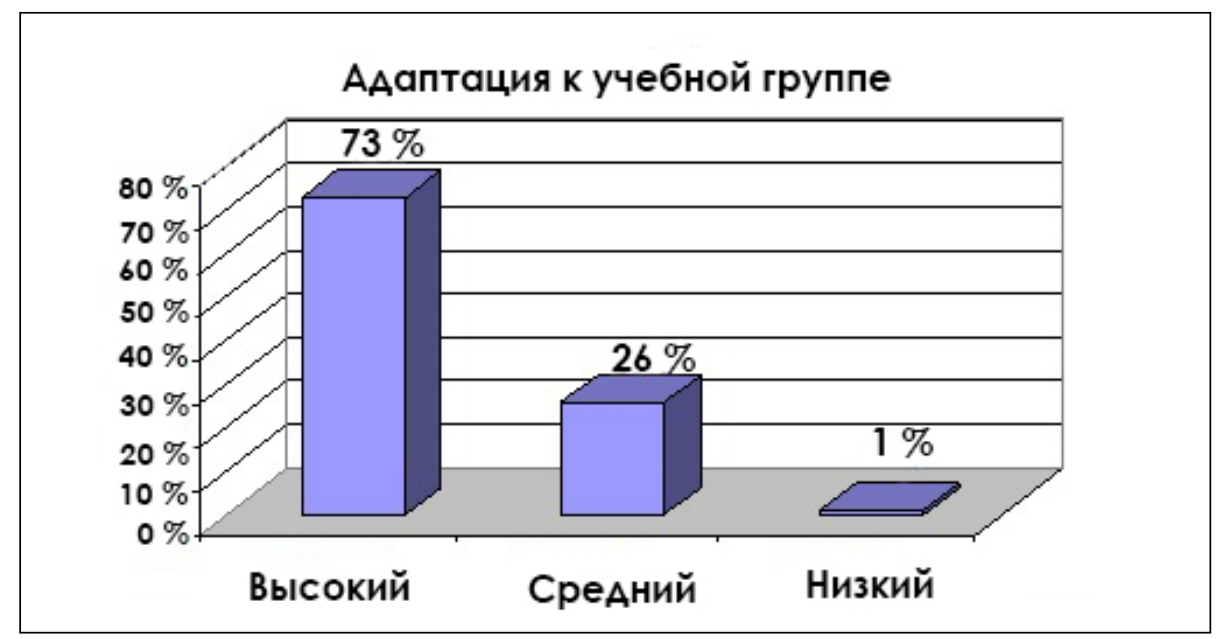

Рисунок 1. График распределения уровней алаптации к учебной группе в выборке испытуемых 
МУЛЛЕР О. Ю., РОТОВА Н. А.

СОЦИАЛЬНО-ПСИХОЛОГИЧЕСКАЯ АДАПТАЦИЯ СТУДЕНТОВ К ОБУЧЕНИЮ В ПЕДАГОГИЧЕСКОМ ВУЗЕ

РосСИйский психологИЧЕСКИй жУРнАл, 2020, Т. 17, № 3, 18-29. doi: 10.21702/rpj.2020.3.2

ПЕДАГОГИЧЕСКАЯ ПСИХОЛОГИЯ

Полученные данные диагностики свидетельствуют о том, что большая часть - 73 \% (76 человек) студентов факультета показала высокую адаптированность к взаимодействию в учебной группе. Данные свидетельствуют о том, что студенты чувствуют себя комфортно, в случае необходимости им не составляет труда обратиться за помощью к одногруппникам, студенты достаточно активно высказывают свою позицию, что позволяет взять инициативу в свои руки в группе. Студенты групп факультета психологии и педагогики способны принять и поддержать взгляды и интересы одногруппников.

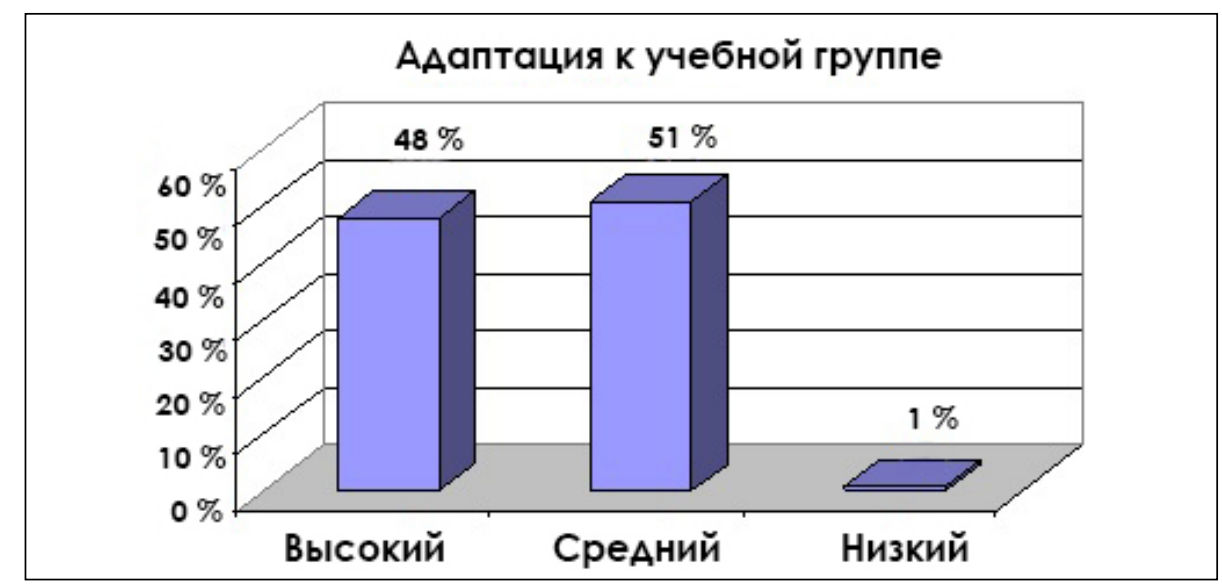

Рисунок 2. Граффик распрелеления уровней алаптации к учебной Аеятельности в выборке испытуемых

Средний уровень адаптированности в учебной группе наблюдается у $26 \%$ (27 человек) студентов, прошедших опрос. Особенности адаптированности характеризуются относительно комфортным ощущением студентов в группе. Кроме того, студентам присуще проявление сдержанности во взаимоотношениях, также наблюдается проявление сложностей в принятии решений в некоторых ситуациях.

Низкий показатель адаптированности в учебной группе выявлен лишь у 1 \% (один человек) из числа опрошенных. Полученные данные свидетельствуют о том, что студент сдержан в общении, осторожен, не разделяет принятые в группе правила, и, соответственно, одногруппники не поддерживают его взгляды, в результате чего он не может обратиться к ним за помощью. Работа с таким студентом предполагает более пристальное внимание со стороны психологической службы, куратора, студенческой группы и преподавателей. Преподавателю следует обратить внимание на содержание той ситуации, в которой такой студент оказался в вузе. Причин может быть несколько: как недостаточный уровень знаний и умений, необходимых для усвоения учебных дисциплин в вузе и овладения профессиональными компетенциями, так и недостаточный уровень развития навыков самостоятельной работы, самоорганизованности, неумение спланировать собственные действия. Это приводит к непониманию студентом смысла учебной деятельности в вузе для овладения будущей профессией. Отсюда эмоциональное напряжение, недостаточно серьезное отношение к выполнению учебных заданий, расхождение во взглядах и интересах с одногруппниками, разочарование в совершенном профессиональном выборе. Помощь такому студенту может быть оказана как со стороны психологической службы, так и со стороны одногруппников, при выполнении заданий в группах на учебных 
МУЛЛЕР О. Ю., РОТОВА Н. А.

СОЦИАЛЬНО-ПСИХОЛОГИЧЕСКАЯ АДАПТАЦИЯ СТУДЕНТОВ К ОБУЧЕНИЮ В ПЕДАГОГИЧЕСКОМ ВУЗЕ

РОССИЙСКИЙ ПСИХОЛОГИЧЕСКИЙ ЖХРнАл, 2020, Т. 17, № 3, 18-29. doi: 10.21702/rpj.2020.3.2

ПЕДАГОГИЧЕСКАЯ ПСИХОЛОГИЯ

занятиях, и со стороны куратора учебной группы, который может включить в тематику кураторских часов необходимую информацию по тайм-менеджменту собственной деятельности, и со стороны преподавателя, которому необходимо давать более четкие инструкции при организации самостоятельной работы студентов.

Одним из важнейших условий успешной социально-психологической адаптации студентов в педагогическом вузе является их удовлетворенность организацией учебного процесса, дающего возможность полноценного получения знаний в рамках педагогического направления подготовки.

Высокие результаты диагностики по шкале адаптированности к учебной деятельности продемонстрировали 48 \% (50 человек). Полученные данные позволяют сделать вывод о том, что этим студентам достаточно легко дается освоение учебных предметов, они вовремя и успешно выполняют задания по учебным дисциплинам; в случае необходимости им легко обратиться к преподавателю за помощью, они могут свободно выражать свои мысли, проявлять свои способности на занятиях.

Средний уровень адаптированности к учебной деятельности продемонстрировал $51 \%$ студентов (53 человека). Это проявляется в том, что освоение некоторых учебных дисциплин вызывает у них определенные сложности (не могут выразить свои мысли, трудно отвечать на занятиях).

Полученные данные низкого показателя адаптированности к учебной деятельности, а это 1 \% (1 человек), свидетельствуют о затруднениях у этого студента во взаимодействии с преподавателями, сложностях при освоении учебных дисциплин, и, как следствие, студенту некомфортно на занятиях. Ему необходимы дополнительные консультации, с таким студентом необходимо планировать индивидуальную работу, т. к. он не может проявить свои способности на учебных занятиях.

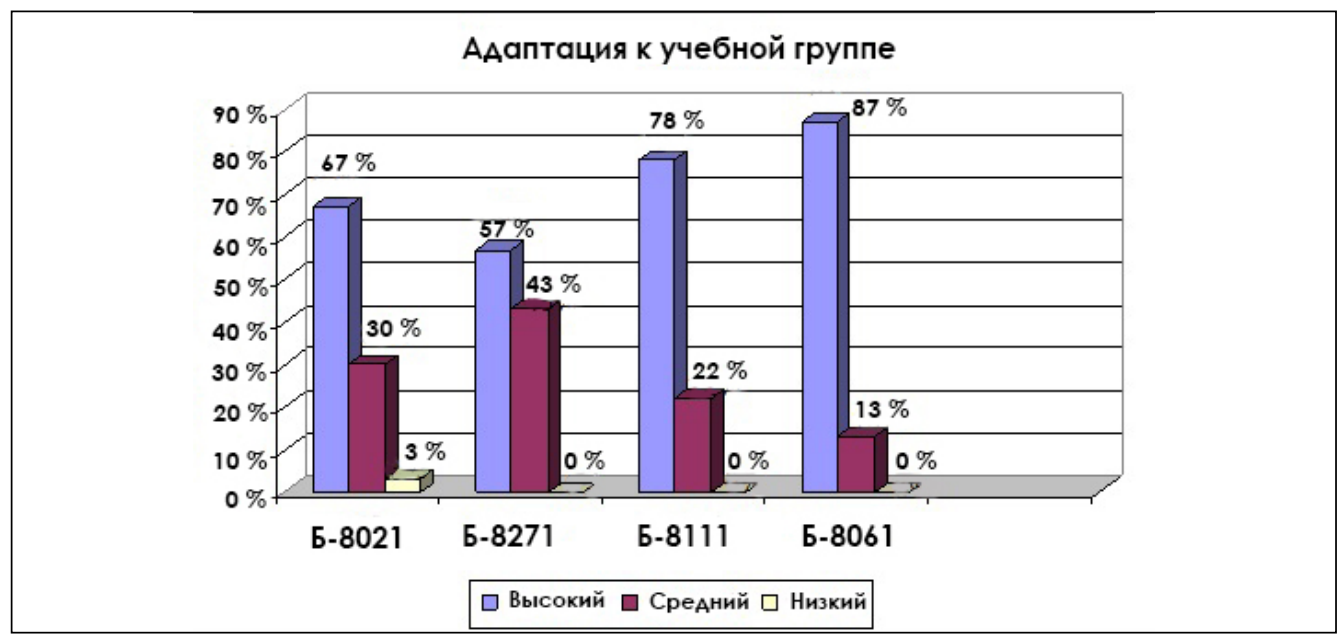

Рисунок 3. График распрелеления уровней алаптации к учебной группе в разных группах

Самый высокий уровень адаптированности к учебной группе у студентов группы Б-8061 (направление «Дошкольное образование»); менее всего по высоким показателям, но более всего по средним адаптировалась группа Б-8271 (направление «Психолого-педагогическое образование»). 
МУЛЛЕР О. Ю., РОТОВА Н. А.

СОЦИАЛЬНО-ПСИХОЛОГИЧЕСКАЯ АДАПТАЦИЯ СТУДЕНТОВ К ОБУЧЕНИЮ В ПЕДАГОГИЧЕСКОМ ВУЗЕ

РоссиЙский псИХологИЧЕСКИй ЖУРнАл, 2020, Т. 17, № 3, 18-29. doi: 10.21702/rpj.2020.3.2

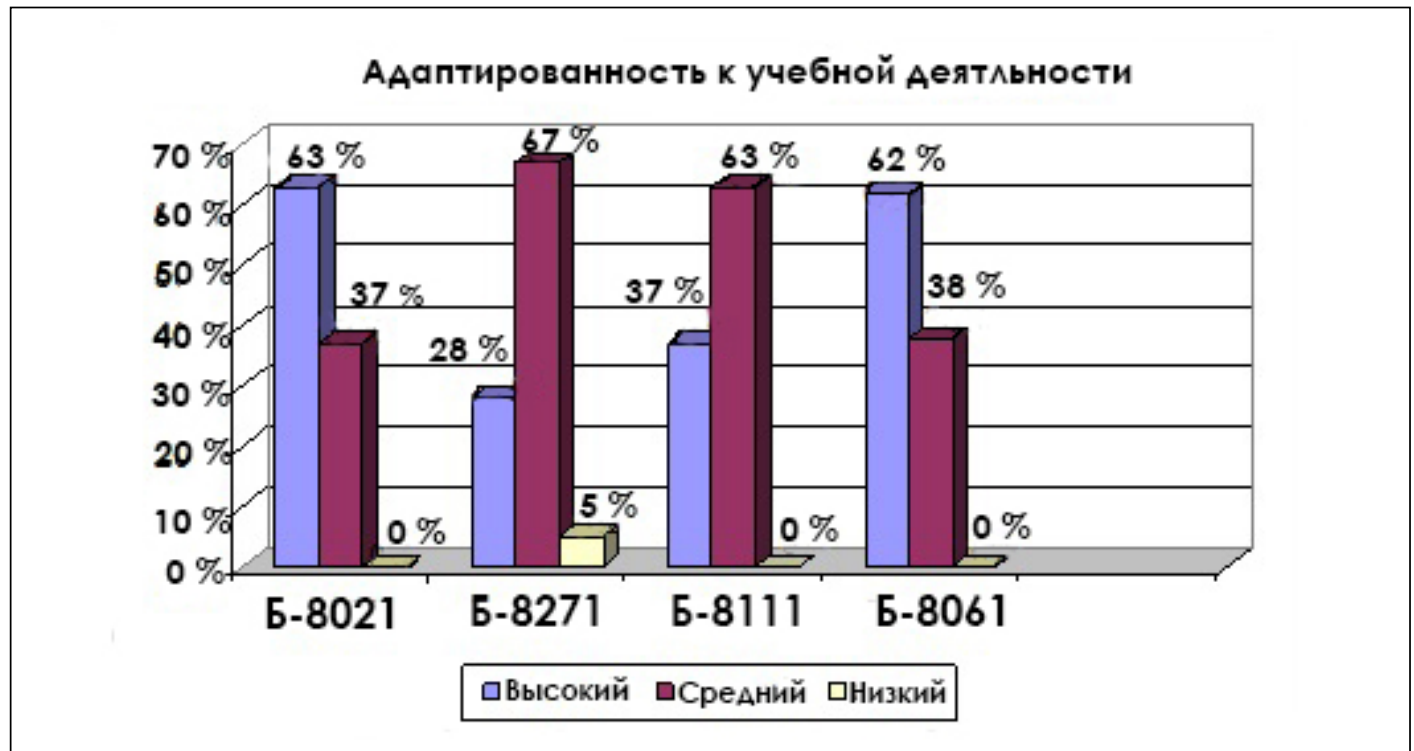

Рисунок 4. График распределения уровней алаптации к учебной Аеятельности в разных группах

На самых высоких уровнях адаптировались к учебной деятельности студенты групп Б-8021 (направление «Начальное образование») и 5-8061 (направление «Дошкольное образование»); менее всего, по количеству низких показателей, адаптировалась группа Б-8271.

Таким образом, анализ полученных данных показал, что у студентов первого курса факультета психологии и педагогики выявлены в целом высокий и средний уровни адаптации, как к учебной группе, так и к учебной деятельности. Эти студенты активны на занятиях, задают вопросы, активно включаются в диалог как с преподавателем, так и сокурсниками; данный результат объясняется тем, что учебная группа - это группа объединенных одним профессиональным интересом людей, поэтому они легко взаимодействуют, им интересны учебные дисциплины, студенты пытаются представить себя на профессиональном поприще. Диагностические показатели адаптации к учебной группе в целом более высокие, по сравнению с адаптацией к учебной деятельности. Однако присутствуют студенты с низким уровнем адаптации. С данными студентами запланирована работа по активизации внутренних ресурсов и повышению уровня адаптационных возможностей, организует которую, в первую очередь, куратор учебной группы, включая самого студента в активное взаимодействие с одногруппниками через кураторские часы, контролируя учебную деятельность студента.

\section{Обсуждение результатов}

Использование диагностических методик в ходе экспериментальной работы позволило подтвердить характерные особенности процесса социально-психологической адаптации студентов к обучению в педагогическом вузе, связанные с адаптацией к учебной деятельности и с адаптацией к учебной группе. Это позволяет сделать вывод о том, что адаптированность студентов педагогического вуза проявляется в их умении выстраивать собственный стиль поведения, а это обусловлено уверенностью студента в правильности совершенного профессионального выбора, активным поиском смысла в выбранной трудовой деятельности. Следует 
МУЛЛЕР О. Ю., РОТОВА Н. А.

СОЦИАЛЬНО-ПСИХОЛОГИЧЕСКАЯ АДАПТАЦИЯ СТУДЕНТОВ К ОБУЧЕНИЮ В ПЕДАГОГИЧЕСКОМ ВУЗЕ

РОССИЙСКИЙ пСИХОЛОГИЧЕСКИЙ ЖУРнАл, 2020, Т. 17, № 3, 18-29. doi: 10.21702/rpj.2020.3.2

ПЕДАГОГИЧЕСКАЯ ПСИХОЛОГИЯ

отметить, что поиск смысла в труде человек осуществляет всю жизнь, однако с первокурсниками именно в период адаптации необходимо организовать психологическое сопровождение, которое поможет осознанию ими смысла профессионального самоопределения.

Выявленные результаты экспериментальной работы дают основание для следующих выводов и направлений их практического применения:

1. Адаптированность студентов к обучению в педагогическом вузе есть результат социально-психологической адаптации; проявляется через сформированность положительного отношения к выбору профессии, саморганизованность.

2. Высокий и средний уровни социально-психологической адаптации студентов к обучению в педагогическом вузе играют ключевую роль в их самоорганизации.

3. При успешной социально-психологической адаптации студентов к обучению в педагогическом вузе необходимо применение преподавателями интерактивных форм взаимодействия в образовательном процессе, что дает студентам возможность поиска собственного смысла в выбранном педагогическом труде, повышает внутреннюю мотивацию к педагогическому направлению подготовки, самостоятельность в принятии решений (Rotova, 2018).

4. Успешность социально-психологической адаптации характеризуется тем, насколько эффективно студенты смогут выстроить общение с преподавателями и сокурсниками на основе собственного стиля поведения, что, на наш взгляд, дает возможность выявить степень осознанности студентом собственного отношения к его профессиональному выбору. Преподаватель в период адаптации, анализируя характер коммуникации со стороны студента-первокурсника, может наблюдать, какой смысл приобретает для него выбранная профессия, насколько велика вероятность самореализации в выбранной профессии, и, следовательно, характер мотивов к будущей профессиональной деятельности.

5. Успешная социально-психологическая адаптация формирует способность студента к преодолению трудностей в учебной деятельности, к самоорганизации.

\section{Заключение}

Следовательно, от успешности процесса социально-психологической адаптации зависит и итог процесса профессионального самоопределения студентов в педагогическом вузе. Именно социально-психологическая адаптация, которая имеет структуру и логику развития, условия успешного протекания, активизирует весь потенциал личностных качеств студентов, является важной причиной, оказывающей влияние на организацию учебной деятельности в педагогическом вузе. Предлагаемые мероприятия по повышению уровня адаптационных возможностей студентов в педагогическом вузе могут быть следующими: вовлечение первокурсников в работу студенческих объединений; включение в волонтерскую деятельность; согласованная работа кураторов и психологической службы вуза; проведение тренингов специалистами психологической службы для сплочения первокурсников; привлечение сокураторов из числа студентов старших курсов; проведение тематических кураторских часов по тайм-менеджменту, эффективной коммуникации; использование преподавателями в работе с первокурсниками интерактивных форм занятий (Sedova, 2017); привлечение студентов-первокурсников к активной профориентационной работе со старшеклассниками в рамках профориентационных мероприятий, таких как мастер-классы во время проведения Дней открытых дверей, что позволит преодолеть трудности в адаптационный период. 
МУЛЛЕР О. Ю., РОТОВА Н. А.

СОЦИАЛЬНО-ПСИХОЛОГИЧЕСКАЯ АДАПТАЦИЯ СТУДЕНТОВ К ОБУЧЕНИЮ В ПЕДАГОГИЧЕСКОМ ВУЗЕ

РоссиЙский псИХологИЧЕСКИй ЖУРнАл, 2020, Т. 17, № 3, 18-29. doi: 10.21702/rpj.2020.3.2

ПЕДАГОГИЧЕСКАЯ ПСИХОЛОГИЯ

\section{Литература}

Бредун, Е. В., Баланёв, Д. Ю., Ваулина, Т. А., Краснорядцева, О. М. и Щеглова, Э. А. (2020). Темпоральные особенности студентов как когнитивные диагностические характеристики: контекст адаптивного образования. Российский психологический журнал, 17(1), 60-73. doi: 10.21702/rрj.2020.1.5

Верченко, И. А. и Гринева, К. Ю. (2015). Оценка успешности адаптации студентов-первокурсников к условиям вуза. Вестник Челябинского государственного педагогчческого университета, 9, 131-135.

Власова, Т. А. (2009). Социально-психологическая адаптация студентов младших курсов к условиям обучения в вузе. Вестник ЧГПУ, 1, 13-22.

Гартман, Э. (2010). Сущность мирового процесса, или Философия бессознательного: Метафизика бессознательного (А. А. Козлов, пер. с нем.). Москва: КРАСАНД.

Гефеле, О. Ф. (2003). Социальная адаптация личности в ситуациях неопределенности. В Ежегодник Российского психологического общества: Материалы 3-го Всероссийского съезда психологов (с. 56-59). Санкт-Петербург: Изд-во С.-Петерб. ун-та.

Дубовицкая, Т. Д. и Крылова, А. В. (2010). Методика исследования адаптированности студентов в вузе. Психологическая наука и образование, 2. Доступ 03 июля 2020, источник https://psyjournals.ru/files/27814/psyedu ru 20102 Dubovitskaya Krilova.pdf

Ермаченко, Н. А., Зайцева, О. В. и Середа, В. А. (2017). Исследование особенностей адаптации первокурсников к условиям обучения в педагогическом вузе. Педагогическое образование в России, 2, 39-45.

Лазарев, В. С. (2011). Концептуальная модель формирования профессиональных умений у студентов. Вестник Сургутского государственного педагогического университета, 2 (13), 5-13.

Лызь, Н. А. и Шостак, А. А. (2016). Роль ресурсов образовательной компетентности школьников в адаптации к обучению в вузе. Вестник Южно-Уральского государственного универсиmета. Серия: Образование. Педагогические науки, 8(4), 30-36. doi: 10.14529/ped160404

Маркарян, Э. (1971). Общество как универсальная адаптивно-адаптирующая система и узловые проблемы генезиса социокультурного типа самоорганизации жизни. Доступ 03 июля 2020, источник https://emarkaryan.info/society 2/

Мечков, К. (1993). Психиката: Същност, структура, организация, дезорганизация. Велико Търново: Пик.

Налчаджян, А. А. (2008). Социально-психическая адаптация личности (формы, механизмы и стратегии). Ереван.

Осницкий, А. К. (2004). Определение характеристик социальной адаптации. Психология и школа, 1, 43-56.

Пряжникова, Е. Ю. и Пряжников, Н. С. (2013). Профориентация: учебное пособие для студентов высиих учебных заведений, обучающихся по направлению и специальностям психологии. Москва: Академия.

Росляков, А. Е. (2003). Социально-психологчческая адаптация студентов в условиях вуза МПС (кандидатская диссертация). Ярослав. гос. ун-т им. П. Г. Демидова, Ярославль.

Свешникова, С. Л. (2019). Временная перспектива как фактор социально-психологической aдаптации (кандидатская диссертация). Ярослав. гос. ун-т им. П. Г. Демидова, Ярославль.

Серева, Д. О. и Андонова, А. Н. (2016). Об адаптации иностранных студентов к поликультурной образовательной среде вуза. Вестник по педагогике и психологии Южной Сибири, 3, 72-82. 
Спаустинайтис, Е. Г. (2015). Социально-психологическая адаптация студентов и развитие эмоционального интеллекта. В Высшая школа: проблемы и перспективы: 12-я Междунар. науч.-метод. конф. В 2 ч. Ч. 2 (с. 85-89). Минск, 2015.

Толстых, Ю. И. (2011). Критерии оценки успешности адаптации студентов-первокурсников в вузе. Известия высших учебных заведений. Поволжский регион. Гуманитарные науки, 4 (20), 137-142.

Artunduaga, A., Muñoz, D., \& Rojas, A. (2018). Impact of pedagogical reflection in the teaching practicum from Caquetá practitioners' perspective: A literature review. Educación y Humanismo, 20(35), 57-73. doi: 10.17081/eduhum.20.35.2658

Beneyto-Seoane, M., \& Collet-Sabé, J. (2018). Análisis de la actual formación docente en competencias TIC. Por una nueva perspectiva basada en las competencias, las experiencias y los conocimientos previos de los docents. Profesorado. Revista de Currículum y Formación del Profesorado, 22(4), 91-110. doi: 10.30827/profesorado.v22i4.8396

Cabello, R., Sorrel, M. A., Fernández-Pinto, I., Extremera, N., \& Fernández-Berrocal, P. (2016). Age and gender differences in ability emotional intelligence in adults: A cross-sectional study. Developmental Psychology, 52(9), 1486-1492. doi: 10.1037/dev0000191

Fan, J. (2016). The role of thinking styles in career decision-making self-efficacy among university students. Thinking Skills and Creativity, 20,63-73. doi: 10.1016/j.tsc.2016.03.001

Kim, L. E., \& Klassen, R. M. (2018). Teachers' cognitive processing of complex school-based scenarios: Differences across experience levels. Teaching and Teacher Education, 73, 215-226. doi: 10.1016/j.tate.2018.04.006

Koeslag-Kreunen, M. G. M., Van der Klink, M. R., Van den Bossche, P., \& Gijselaers, W. H. (2018). Leadership for team learning: The case of university teacher teams. Higher Education, 75, 191-207. doi: 10.1007/s10734-017-0126-0

Maltese, A. V., Simpson, A., \& Anderson, A. (2018). Failing to learn: The impact of failures during making activities. Thinking Skills and Creativity, 30, 116-124. doi: 10.1016/j.tsc.2018.01.003

Ranga, M., \& Etzkowitz, H. (2015). Triple Helix systems: An analytical framework for innovation policy and practice in the Knowledge Society. In Entrepreneurship and knowledge exchange (pp. 117158). New York: Routledge. doi: 10.4324/9781315795638

Rotova, N. A. (2018). Development of independence among future primary school teachers by applying interactive learning methods. Journal of Education and e-Learning Research, 5(2), 118-121. doi: 10.20448/journal.509.2018.52.118.121

Sedova, K. (2017). A case study of a transition to dialogic teaching as a process of gradual change. Teaching and Teacher Education, 67, 278-290. doi: 10.1016/j.tate.2017.06.018

Semmler, L., Uchinokura, Sh., \& Pietzner, V. (2018). Comparison of German and Japanese student teachers' views on creativity in chemistry class. Asia-Pacific Science Education, 4, 9. doi: 10.1186/s41029-018-0025-4

Taylor, S. P. (2017). What is innovation? A study of the definitions, academic models and applicability of innovation to an example of social housing in England. Open Journal of Social Sciences, 5(11). doi: 10.4236/jss.2017.511010

With, M. L. (2017). Are teachers increasingly leaving the profession? Professions and Professionalism, 7(2), e1723. doi: 10.7577/pp.1723

Конфликт интересов отсутствует 